\title{
The Effect of Authentic vs. Non-authentic Materials on Iranian EFL Learners' Listening Comprehension Ability
}

\author{
Samira Alijani (Corresponding author) \\ English Language Department, Khomein Science and Research Branch, Islamic Azad University, Khomein, Iran \\ E-mail: samialijani@yahoo.com \\ Mojtaba Maghsoudi \\ Farhangian University, Arak, Iran \\ E-mail: maghsoudim@yahoo.com \\ Davood Madani \\ English Language Department, Khomein Science and Research Branch, Islamic Azad University, Khomein, Iran
}

\author{
Received: 04-01-2014 \\ doi:10.7575/aiac.ijalel.v.3n.3p.151
}

Accepted: 10-02-2014

Published: 01-05-2014

URL: http://dx.doi.org/10.7575/aiac.ijalel.v.3n.3p.151

\begin{abstract}
The main goal of this study was to examine the influences of authentic materials on listening ability of sixty female language learners. To this aim, sixty Iranian EFL learners in upper-intermediate level who studied in two institutes in Esfahan were participated to this study. They were divided into two groups. This division was done randomly. At the end a t-test was applied and the data analysis revealed that experimental group surpassed their peers in control group in listening comprehension ability since they received treatments through authentic materials. In this paper the results revealed that the authentic materials have benefit for EFL classrooms for the lack of real opportunities that will be existed for learners to be encountered with it while learning.
\end{abstract}

Keywords: authentic materials, non-authentic materials, listening comprehension, authentic language

\section{Introduction}

It is obvious that listening is in the core of language learning and it is the main source of providing input for language learners. If students cannot understand the message of the speaker, they cannot perform in right path as well. As Osada (2004) explained that language learners cannot learn anything without understanding the inputs. Students by listening to lectures in class can learn something and as a result they can keep this information in their mind for later recall (Thanajaro, 2000). Morley (1990) explained that in the past; listening comprehension was treated as a passive activity, but after that theorists found that not only listening isn't a passive activity, but also it is an active one, in which through a process we can construct meaning from a stream of sounds (McDonough, 1999 \& Rivers, 1987).

In the field of second language acquisition (SLA) research, linguistic environment use as the stage of SLA. Actually linguistic environment is the speaker of target language and her/his speech to the L2 learners. So by this environment, language learners can receive input in the form of listening, which contain social and academic situations too (Rost, 2002). This is English as a foreign language (EFL) situation in which English isn't the prominent language and it is used just for teaching some fields in the classroom. So students have not any direct contact with English language in the society. As a result students who come from these situations have very difficulty in understanding English spoken language of native speakers. One of the best ways to improve EFL learners' listening comprehension is using authentic materials in language classrooms. Scholars (Sanderson, 1999, Richards, 1983, \& Rost, 2001) found that authentic materials are valuable because they contain natural language which students may encounter it in real situation. Then students get familiar with structure of real language. Using authentic materials is very simple activity, because it is just picking up examples of language which produced by native speakers for some real purposes. So they are different from the language classroom which is designed solely for language learning purposes. Simply we can ask students to bring a newspaper article into the classroom as an authentic material or an advertisement, their favorite animations, songs, episodes of famous films in order to familiar with real language. Authentic materials, especially audio-visual ones such as films or advertisement, provide much richer input for language learners (Gilmore, 2007). Rogers and Medley (1988) proposed there is a necessity for students to experience the real language which native speakers were used it in daily communication. Remember that there is no need to understand the whole message; it is good if students get only part of it. This can be motivating students to discover the answers of listening tasks. Cook (1981) believed that students with this kind of motivation can get more benefits from authentic materials, and in this way they can close more to the target culture without actually living in the country. He continued that the content of the materials aren't very important, and students shouldn't worry about understanding it or not, because the main reason for using authentic materials is that try to keep students' interest in foreign culture alive (Cook, 1981). We can conclude that if students cannot understand part 
of the message it isn't problematic, since this occurs most of the time in real life (Morley, 2001). As a result instead of boring commercial materials, teachers can bring authentic listening-viewing materials to their classrooms.

\subsection{Problem statement}

Listening is the communicative skill we use most in daily life; this skill can be difficult if you live in foreign country. The probable solution may be is finding different kind of listening materials in target language and listen as often as possible. Most of the students complained that they cannot understand the message of native speakers (out of the classroom); this is because of absence of using natural language in the language classrooms. The language which is used in the classroom doesn't reflect the real language which native speakers are used in their daily communications. The purpose of teaching listening should be allowing learners to be independent in real world encounter with real language (Miller, 2003). Asher (1972) believe that listening comprehension has a significant role in language teaching but typically, classroom activities do not provide students with natural language or real language. The means for achieving this purpose is authentic materials. Unfortunately still in some classes teachers test listening instead of teach it. According to River (1987) the purpose of listening activity should be to teach rather than to test. In this situation students don't learn how to listen, and they are just in hurry to find the answers of proceed tasks followed by listening. As a result they have stress and they lose positive attitude to the listening. The emphasis should be more on functional listening toward the development of listening process, and less on memory and recall of details heard (Morley, 1990). Thus we as teachers should be aware of real needs of students and prepare them to cope with English outside the classroom. This can achieve by using authentic listening materials.

\section{Review of Literature}

Most of the listening classrooms are not match with real life listening. Thus in order to train good listeners for real life communications, it is necessary to provide students with such kind of listening that prepare them for better performance outside of the classroom (Ur, 2012). Since the purpose of English language classes is preparing students to master English language in order to survive in foreign culture, teachers should avoid speech modification as well as simplifications which mislead students and instead provide them with ample opportunities of listening materials that they may encounter with them in real life situations. Tomlinson (1998) explained simplified texts as texts which made simpler for students, in this way they can read/listen them more easily because, there are no long texts, no difficult words and structures, and no additional details. In addition teachers should provide language materials with different topics in order to preparing students with different situation outside of the classroom (Iravani \& Mousavi, 2012). Ur (2012) said, one advantages of using authentic materials in language classes in the form of practical usage, is its motivation which lead students to do something in a task. Thus in order to prepare students to behave correctly to the spoken language outside the classroom teachers should bring as much as possible amount of sample natural language into classrooms. Thus teachers can apply materials adaptation which Tomlinson (2012) explain as applying some changes in materials due to make them more suitable for our students and our special goal in the classroom. Materials adaptation can be include omission or reduction of some parts, addition of some topics, modification and supplementation. This process can achieve by using authentic materials as supplementary materials and increase the listening comprehension ability of students. There are different definitions of authentic materials among literatures. Nunan (1988) define authentic materials as materials which produced for purposes other than to teach language. Thus authentic materials are those which can be oral and written language that used in daily situations by native speakers of that language (Rogers and Medley, 1988). On the other hand non-authentic materials are made by nonnative speakers and usually are simplified form of authentic materials. Authentic listening materials involve some kinds of natural and spontaneous spoken language. They are in different forms and there are variable structures in different dialect and among different people (Lam, 2002). To compare with non-authentic materials, authentic listening materials contain background noise. According to Ur (1984) noise is the opposite of redundancy and most of the time when listener cannot understand the message of the speaker because of interference, it occurs.

By using authentic materials and real-world tasks in language classrooms, students can find a connection between the content of the class and real life situation (Brown, 2001). Rogers (1988) explained that, authentic materials can meet the learners' need and interests, in addition close them more and more to real communication. Using authentic materials make learners more readily dive into the activities. Based on these definitions of authentic materials, many listening textbooks which are published in Iran usually contain the recorded speech with a little noise. The intonations are smooth and there aren't any kinds of mispronunciations which occur often in daily speaking of native speakers. As a result if students are received just such kind of slow and clear English listening, they faced with difficulty in communicating with English native speakers in real situations. It may be due to failing to follow the speed of speech and they may don't understand some idioms and slangs which are common in English language.

Brown and Yule (1983) summarize spoken language as follow:

1- Spoken language has simpler structure than written language.

2- Incomplete sentences are common in spoken language.

3- The amount of vocabulary is less in spoken language than in written one.

4- In spoken language interactive expressions like hum, well, oh are frequently used.

5- The density of information in spoken language is less than writhen language. We can conclude that the vocabularies in authentic listening materials are different with non-authentic materials. 
In addition Ur (1984) suggested that if we cannot use entirely authentic speech, its ok it approximate to real language. According to Nunan (1988) language learners should receive more and more authentic materials as possible, because if they used to listen to planned dialogues and listening tasks, they will face more difficulties in learning tasks. Gebhard (2009) suggested that authentic material is a way to contextualize language learning. By using authentic materials, we present students with a valuable source of language input, thus students don't expose only to language presented by textbook. Field (1998) argued that if we inform students in advance that we don't expect them to understand the whole messages, they feel relax and find authentic materials motivating, consequently they try to discover the information from a real passage. As Guariento and Morley (2001) expressed the best level for this purpose is at post-intermediate level. This is because in this level students learn a lot of vocabularies in target language (Kilickaya, 2004). Thus providing authentic materials in lower levels maybe de-motivated students. In the follow we list the importance of using authentic materials in the classrooms which proposed by Brosnan, D., Brown, K., and Hood S (1984):

1. Since the language is natural we shouldn't simplify it for teaching purposes, because in this way we may omit the important clues for understanding meaning.

2. Authentic language in spite of their small amount -due to lack of enough time in language classroom- involve sufficient meaningful messages.

3. In authentic materials students can get benefit from non-linguistic clues to discover meaning more easily.

4. Authentic materials connect the classroom environment to the real life very soon and clearly.

Altogether when we want select authentic materials we should focus on following criteria which McGrath (2002) presented:

1. Authentic materials should be relevant to syllabus and to learners' needs.

2. Intrinsic interest of topic/theme.

3. Cultural appropriateness.

4. Linguistic demands.

5. Cognitive demands.

6. Logistical considerations: e.g. length, legibility/audibility, quality (as a model of use or as a representative token of a text-type).

7. Exploitability".

To ensure whether an authentic material has had any possible effect on the listening comprehension, I decided to check it by focus on general English of students. In the process of carrying out this study we can't judge just by focusing on the results of listening comprehension, because the ultimate goal is that students can perform well in real situation, this may reveal by students' claims.

Al together, this research study seeks to examine the effect of authentic listening materials on Iranian EFL learners' listening comprehension, so the primary research question is:

1. Is there any difference between authentic and non authentic materials in developing Iranian EFL learners' listening comprehension ability?

And also the secondary research question based on the relationship between general English and listening comprehension ability was formulated as follow:

2. Is there any interaction between Iranian EFL learners' listening comprehension ability and their general English proficiency?

\section{Method}

\subsection{Participants and settings}

60 EFL students from two English institutes were participated in this study. Let it not remain unsaid that the present researchers firstly had to select one hundred female students who were studying English at language learning institutes (Jahad and Ferasat). To make sure of homogeneity of the subjects, the researcher applied a general English proficiency test, Nelson-250 A. Based on the result of proficiency test, 60 students were excluded. The remaining who had similar proficiency in English were utilized as participants in this research. Then they were divided into 2 experimental and control groups. They were in the 18-35 age range. Investigator notified students that their participations in this study is indeed their presence in the class from the beginning to the end of the semester and taking part in pre and post tests. In order to obtain accurate results researcher didn't inform students with the purpose of the study. In this research simple random sampling was used to divide the learners in control and experimental groups.

\subsection{Instrumentation}

In this research study by authentic materials we mean authentic texts that are not written for language teaching purposes. On the other hand non-authentic materials are texts which produced for the sake of teaching and sometimes they are simplified forms. According to McDonough and Shaw (1993), authenticity of language materials, activities, and methods which are used for practice in language classrooms, define as close as possible to the real world outside the classroom.

As a result the main instruments of this project were: 
a) Authentic listening comprehension materials

b) Non-authentic listening comprehension materials

In addition to comparing the general English level with listening comprehension ability we used a standard test. We select Nelson test 250 A (intermediate level), to find the right level of students and compare the results with their listening comprehension ability.

\subsection{Procedure}

Researchers in control and experimental group started the treatment with some pre-listening activities, and introduced the topic to the subjects and prepared them for discussion, then worked on vocabularies and their pronunciations. When people in real life want to listen to something they have background about the topic. For example when they listen to an interview with a famous person they know something about him/her. This is unfair if we want students to listen to pieces of information and then answerer to prepared questions. In pre listening stage, researchers by introducing the topic gave the subjects a background about the listening. Then they focused on critical words (key words) and worked on their meaning and pronunciations. After that, the brain storming activity was applied; this could motivate them to get closer to the topic. Sometimes researchers worked on grammar areas that may represent in listening. At last researchers encouraged the subjects to discuss about the topic of listening. After that in experimental group the researchers played the audio or video authentic listening tape, on the other hand in control group they worked on the normal listening activities which were provided in their books (Top-Notch). At the end subjects in experimental group, should have done something with listening. For example they usually made a conversation with new vocabularies, but in control group subjects should have answered questions in their books. In this stage (while listening) researchers used predetermined questions in order to push the subjects to listen to the tape purposefully.

While subjects in both groups listened to the tapes, the researchers requested them to get the main idea of the text. Then in replaying the tape for few times they should have taken notes and elaborated the meaning of some words or clauses. It means that at last stage (post listening) functional language was examined. All in all the main difference between experimental and control groups was that experimental group received authentic voice as treatment while the control group received the non-authentic material as treatment. In both groups learners listen to audio-visual listening materials, but these kinds of materials in experimental group was authentic video taped and on the other hand in control group the teacher provide some non-authentic videos for listening tasks as supplementary materials, since they were produced for the sake of teaching and the language was simplified.

\section{Results}

In the beginning of semester the listening comprehension ability of the subjects of both mentioned institutes were checked through a pre-test.

Table 1. Comparison of pre-tests in control and experimental groups

\begin{tabular}{rlrrrrr}
\hline Institute & $\mathrm{N}$ & Mean & Std. Deviation & $\mathrm{t}$ & $\mathrm{df}$ & Sig \\
\hline Experimental group & 30 & 26.1471 & 4.41947 & .315 & 58 & .754 \\
\hline Control Group & 30 & 25.6471 & 4.81539 & & & \\
\hline
\end{tabular}

As you see in table 1, the mean score of language learners in pre-test in Ferasat institute is 26.15 with standard deviation of 4.42, and the mean score of language learners in Jahad institute is 25.65 with standard deviation of 4.82.

Applying the independent t-test revealed that there is no significant difference between the mean scores of pre-tests in two institutes.

Table 2. Comparison of listening comprehension scores at the end of the study

\begin{tabular}{rlccccc}
\hline Institute & $\mathrm{N}$ & Mean & Std. Deviation & $\mathrm{t}$ & $\mathrm{df}$ & Sig. \\
\hline Authentic & 30 & 35.4853 & 5.71967 & 4.83 & 58 & .000 \\
Non-authentic & 30 & 26.4706 & 5.12643 & 9 & & \\
\hline
\end{tabular}

Table 2 shows the results of listening comprehension test in both Jahad (control group) and Ferasat (experimental group) institutes. The mean score of subjects' listening comprehension in Ferasat institute was 35.49 with standard deviation of 5.72, and the mean score of subjects' listening comprehension in Jahad institute was 26.47 with standard deviation of 5.13.To compare the mean scores of subjects' listening comprehension ability in both institutes t-test was utilized. Data analysis revealed that those subjects who received authentic materials in their treatment (experimental group) surpassed their peers who received non-authentic material (control group). 
Table 3. Analysis the relationship between general English proficiency and post-test in two institutes

\begin{tabular}{rccc}
\hline Institute & $\mathrm{N}$ & $\begin{array}{c}\text { Pearson } \\
\text { Correlation }\end{array}$ & Sig. \\
\hline Authentic & 30 & .304 & .235 \\
\hline Non-authentic & 30 & .299 & .244
\end{tabular}

Table 3 shows the relationship between language learners' general English and their listening comprehension ability. In order to analyze the relationship between general English proficiency and post-test in two institutes we use Pearson correlation. In both institutes, correlation between post-test and general English proficiency, is positive value, but in two cases the significance level of the test $\mathrm{p}=0$, is more than 0.05 . Therefore, in error level of five percent the assumption of independency of post-test scores and general English proficiency cannot be rejecting. As a result in both institutes, there is no relation between post-test and general English proficiency.

Thus, students with different level of general English proficiency, perform differently on listening comprehension. The observations of the researcher revealed that students who gained higher degrees in language proficiency, had serious problems in listening comprehension.

\section{Discussion}

According to Ghaderpanahi (2012) EFL students who had experienced authentic listening materials, showed listening comprehension improvement, and also Mousavi and Iravani (2012) concluded the main means for preparing students to perform accurately to the spoken language outside the classroom, is providing sample of natural or real language i.e. authentic language in the classroom. In addition Miller (2003) examined the authentic listening materials' implications in language classrooms. His focus was more on division of listening exercises into three different parts (pre, while, and post listening activities). He suggested implementing authentic listening materials by focus on these activities is easier, and students listen for pleasure not test.

The very first objective of this study was to examine the influences of authentic materials on the listening comprehension in Iranian EFL students. The secondary objectives were to evaluate the effect of general English on listening comprehension. This research study is an attempt to show the value of the authentic materials in developing listening comprehension of Iranian EFL students, because we believed that listening to authentic materials prepare students more to encounter with real situation. Thus we use authentic materials in our listening class (experimental group) and compare the listening comprehension of students in control group, who didn't received authentic treatment.

The analysis of obtained data from pre-test, post-test and group discussions revealed that the use of authentic listeningviewing materials in EFL classroom helped increased students' listening comprehension ability. The students' listening comprehension appeared to have improved after having exposed to aural and visual authentic materials in the classroom. Researcher's observations revealed that students were very satisfied with authentic materials, since this was a new experience for them. They became more interested in listening activities after that. It was nice for researcher that some students bring their authentic materials and work on them in group. By comparing the results we found that level of general English of students had no positive effect on listening comprehension, thus students with better performance on general English have not necessarily better performance on comprehension of authentic listening.

In language classes the comprehension is an important factor. Comprehension becomes more important when we speak about the listening skill. Listening comprehension refer to ability to decode information from auditorially language (Krashen, 1985). Learners should understand both the main idea of listening activities in class, and messages of English speakers out of the class. In compare with other skills, listening were used frequently both in language classroom and daily communications (Nunan, 1988). As a result we should put more attention on listening in language classes. This skill becomes more difficult for EFL language learners, because they are far from natural language, and they miss hearing authentic language as well. Authentic language reflects forms in natural way, and show clearly cultural and situational context (Rogers \& Medley, 1988). So students in order to be a member of English community should be able to understand natural speech and try to cope with genuine speech and authentic listening (Rost, 2002).

\section{Conclusion \& Pedagogical Implication}

At the end of the study it was concluded that using authentic materials in language classes would be more fruitful for EFL learners than non-authentic ones. Of course based on the advantages of authentic materials we deduced they are useful and applicable. Anderson and Lynch (1988) believed that if students want to a successful listener in real life should be more active in listening process. As you know the primary reason for learning a new language is to become closer to its culture and people. To this aim we suggest authentic materials which naturally reflect everyday life. As a result in order to be a good listener and also better performance in real life communication, authentic language is essential in language classes.

Thus implementing natural language in language class, improve listening comprehension of students. In this case they get familiar with the various features of authentic language, they can improve their vocabulary knowledge; learn more idioms, slangs, and abbreviations. As you see, the results of the study show after a complete semester students' listening comprehension were improved due to exposure to authentic materials. When researcher ask about the students' attitudes toward using authentic materials, they all have positive view to it, and claimed that sometimes they were difficult for them, but when they understand it, it becomes sweet and interesting. 
The findings of this study showed that listening comprehension of Iranian EFL students was improved after using authentic listening materials in the classroom. Implication of this is that authentic materials have benefit for every language classrooms, special for EFL situations since in this situation students have few opportunities to encounter with real language. It is necessary to use both authentic audio-tapes and video-tapes materials, because authentic audio-tapes materials are failed to give students nonlinguistic features and cultural interactions. In addition nonverbal cues are very useful for listener to understand the message of the speaker. Results indicate that such materials not only increase the degree of listening comprehension but also increase students' motivation and their interest toward listening. It was explained that based on the high level of language proficiency we cannot expect better performance on listening comprehension. In conclusion an implication is, to provide a course in developing academic skills (like comprehension of a lecture) prior to the students' entering academic classes.

\section{References}

Anderson, A., \& Lynch, T. (1988). Listening. New York: Oxford University Press.

Asher, J. (1972). Children's first language as a model for second language learning. Modern Language Journal , 56 (5), 133-139.

Brosnan, D., Brown, K., \& Hood S. (1984). Reading in context. Adelaide: National Curriculum Resource Center.

Brown, H. D. (2001). Teaching by Pronciples: an interactive approach to language pedagogy. Longman.

Cook, V. (1981). Using Authentic Materials in the Classroom. Retrieved Des 6, 2012, from ntlworld: http:/homepage.ntlworld.com/vivian.c/Writings/Papers/AuthMat81.htm

Field, J. (1998). Skills and strategies: Towards a new methodology for listening. ELT, 52 (2), 110-119.

Gebhard, J. (2009). Teaching English as a Foreign/Second. Ann Arbor, MI: The University of Michigan Press.

Guariento, W. \& Morely, J. (2001). Text and task authenticity in the EFL classroom. ELT , 55 (4), 347-353

Iravani, H., \& Mousavi, S., A. (2012). The Effect of Authentic Versus Non-authentic Aural Materials on EFL. English Language and Literature Studies , 2 (1), 21-27.

Kilickaya, F. (2004). Authentic Materials and Cultural Content in EFL Classrooms. The Internet TESL Journal , $x$ (7), 58-69.

Krashen, S. D. (1985). The input hypotheses: Issues and implications. New York: Longman.

Lam, W. Y. (2002). Methodology in Language Teaching: An Anthology of Current Practice. Cambridge : Cambridge University Press.

Miller, L. (2003). Developing Listening Skills With Authentic Materials. ESL Magazine , 6 (2), 16-18.

Morley, J. (1990 ). Trends and developments in listening comprehension: Theory and practice. Washington, DC: Georgetown University Press.

Gilmore, A. (2007). Authentic materials and authenticity in foreign language learning. Language teaching, 40(2), 97118.

Morley, J. (2001). teaching english as a second or foreign language (3rd ed.). (M. Celce-Murcia, Ed.) United kingdom : Heinle \& Heinle.

McGrath, I. (2002). Materials Evaluation and design for language teaching. Edinburgh: Edinburgh University Press.

McDonough, S. H. (1999). Learner strategies (Vol. 32). Cambridge : Cambridge University Press.

Nunan, D. (1988). The learner-centred curriculum. Cambridge : Cambridge university Press.

Osada, N. (2004). listening comprehension research: a brief review of the past thirty years. International Journal of Learning \& Development , 3 (1), 53-66.

Sanderson, P. (1999). using newspaper in classroom. Cambridge: Cambridge Univesity Press.

Richards, J. (1983). Listening comprehension: Approach, Design, Procedure TESOL Quarterly. 2, pp. $219-239$.

Rivers, W. M. (1987). Interactive language teaching. Cambridge: Cambridge University Press.

Rogers, C. V., \& Medley, F. W. (1988). Language with a purpose: Using authentic materials in the foreign language classroom. Foreign Language Annals , 21, 467-478.

Rost, M. (2001). The Cambridge Guide to Teaching English to Speakers of Other Languages. (R. C. Nunan, Ed.) United Kingdom: Cambridge University Press.

Rost, M. (2002). Teaching and researching listening. New York: Pearson

Thanajaro, M. (2000). Listening with Authentic Materials. the modern language jornal , 3, 105-116.

Tomlinson, B. (1998). materials development in language teaching. Cambridge: Cambridge University press.

Ur, P. (1984). teaching listening comprehension. New York: Cambridge University press.

Ur, P. (2012). A Course in English Language Teaching . Cambridge: Cambridge University press.

Yule, G., \& Brown, G.(1983). teaching the spoken language. United Kingdom: Cambridge. 